\title{
Penggunaan Metode Ganjaran dalam Meningkatkan Motivasi Belajar Bahasa Arab
}

\author{
Yusnindar Abd Gani*, Yeni Lailatul Wahidah \\ Universitas Islam Negeri Sunan Kalijaga Yogyakarta \\ Corresponding author: *yusnindarabdulgani@gmail.com
}

\begin{abstract}
This study aims to reveal descriptively about the use of learning methods in improving students' learning motivation in Mas Bahrul Hikmah Konawe North Sultra to find out what methods are applied during the learning process at Mas Bahrul Hikmah Konawe Utara and to find out how the motivation of student learning Mas Bahrul Hikmah Konawe North. The method used in this research is descriptive qualitative method in order to give explanation about the use of learning method in improving students' learning motivation Arabic in Mas Bahrul Hikmah Konawe Utara Sultra. The data obtained through interviews with informants research related to the achievement of the purposes of research. Subjects in this study were teachers and students at Mas Bahrul Hikmah Konawe Utara Sultra. The result of the research are: (1) The method applied when the learning process of Arabic language in Mas Bahrul Hikmah is, conversation method or muhadatsah, the method of reading that is qira'ah (muthala'ah), grammatical method or qowa'id (al-kitabah) and Listening method (al-istima'i) this method is commonly used when imla learning process, besides using special method of learning Arabic language also using general methods, such as lecture method, discussion method, group work method, question and answer method and method Assignment. There is also a new method addition, reward method. The reward method applied is the method of punishment and reward method. (2) The use of reward method in Mas Bahrul Hikmah is very effective besides can grow student's motivation in learning also help student get high test value, because after use method of reward value of student exam much increase.
\end{abstract}


Penelitian ini bertujuan untuk mengungkapkan secara deskriptif tentang penggunaan metode pembelajaran dalam meningkatkan motivasi belajar bahasa Arab siswa di Mas Bahrul Hikmah Konawe Utara Sultra untuk mengetahui metode apa saja yang diterapkan selama proses pembelajaran di Mas Bahrul Hikmah Konawe Utara dan untuk mengetahui bagaimana motivasi belajar siswa Mas Bahrul Hikmah Konawe Utara. Metode yang digunakan dalam penelitian ini adalah metode kualitatif deskriptif guna memberikan penjelasan mengenai penggunaan metode pembelajaran dalam meningkatkan motivasi belajar bahasa Arab siswa di Mas Bahrul Hikmah Konawe Utara Sultra. Data yang diperoleh melalui wawancara dengan informan penelitian terkait dengan pencapaian tujuan penelitian. Subjek dalam penelitian ini adalah guru dan siswa di Mas Bahrul Hikmah Konawe Utara Sultra. Hasil penelitian dapat disimpulkan: (1) Metode yang diterapkan ketika proses pembelajaran bahasa Arab di Mas Bahrul Hikmah adalah, metode percakapan atau muhadatsah, metode membaca yaitu qira'ah (muthala'ah), metode gramatika atau qowa'id (al-kitabah) dan metode mendengarkan (al-istima'i) metode ini biasa digunakan ketika proses pembelajaran imla', selain menggunakan metode khusus pembelajaran bahasa Arab juga menggunakan metode-metode umum, seperti metode ceramah, metode diskusi, metode kerja kelompok, metode tanya-jawab dan metode pemberian tugas. Adapula tambahan metode baru yaitu, metode ganjaran. Metode ganjaran yang diterapkan yaitu metode pemberian hukuman dan metode pemberian hadiah. (2) Penggunaan metode ganjaran di Mas Bahrul Hikmah sangatlah efektif selain bisa menumbuhkan motivasi siswa dalam belajar juga membantu siswa memperoleh nilai ujian yang tinggi, karena setelah penggunaan metode ganjaran nilai ujian siswa banyak meningkat.

Keywords: Metode pembelajaran; motivasi belajar; Mas Bahrul Hikmah.

\section{Pendahuluan}

Bahasa adalah realitas yang tumbuh dan berkembang sesuai dengan tumbuh kembangnya sesuai dengan tumbuh kembangnya manusia pengguna bahasa itu. Realitas bahasa dalam kehidupan ini semakin menambah kuatnya eksistensi 
manusia sebagai makhluk berbudaya dan beragama. ${ }^{1}$ Secara umum, bidang ilmu bahasa dibedakan menjadi linguistik murni dan linguistik terapan. Bidang linguistik murni mencakup fonetik, fonologi, morfologi, sintaksis, dan semantik. Sedangkan bidang linguistik terapan mencakup pengajaran bahasa, penerjemahan, leksikografi, dan lain sebagainya. bidang pengajaran dan pembelajaran bahasa termasuk salah satu bidang yang tidak banyak menemukan inovasinya akhir-akhir ini. Minimnya inovasi ini disebabkan oleh matinya kreativitas guru, mahasiswa, pemerhati, dan pengkaji bahasa Arab untuk menemukan dan bertanggung jawab ikut serta dalam memecahkan fenomena masalah dan problem fundamental yang menjadi penghambat pendidikan bahasa Arab yang tidak jelas arahnya seperti terjadi saat ini. ${ }^{2}$

Pembelajaran bahasa Arab sudah lama dilakukan di Indonesia, namun hasilnya belum sepenuhnya maksimal. Berbagai problem masih sering bermunculan dan hampir jarang terpecahkan. Problem pengajaran bahasa Arab tersebut sekarang sangat perlu segera mendapatkan penanganan serius. Problem tersebut dapat dilihat dari beberapa faktor, yaitu siswa kurang siap mengikuti pelajaran bahasa dan kompleksitas materi bahasa Arab yang menjadikan tingkat kesulitan tinggi pada teknik, strategi, serta metode penyampaiannya. ${ }^{3}$

Aktivitas pengajaran bahasa Arab sebagai inti proses pendidikan tidak berjalan sewajarnya. Guru sebagai salah satu pemegang utama pengajaran bahasa lebih banyak berpaku pada buku paket (text book oriented) dan sulit menciptakan suasana pembelajaran kreatif, inovatif, dan menyenangkan.

${ }^{1}$ Acep Hermawan. Metodologi Pembelajaran Bahasa Arab. (Bandung: PT Remaja Rosdakarya, 2011), cet. I, hlm. 8.

2 Fathul Mujib, Nailur Rahmawati. Metode Permainan-Permainan Edukatif Dalam Belajar Bahasa Arab. (Yogyakarta: Diva Press, 2011), cet. I, hlm. 6 .

${ }^{3}$ Fathul Mujib, Nailur Rahmawati. Metode Permainan-Permainan Edukatif Dalam Belajar Bahasa Arab... Hlm. 6. 
Faktor lain yang menjadi penghambat pembelajaran bahasa Arab saat ini di antaranya adalah heterogenitas siswa, sarana yang kurang memadai, siswa yang kurang aktif dalam KBM (kegiatan belajar mengajar), beban materi banyak, dan jumlah siswa yang banyak (kelas besar) yang tidak semuanya memiliki dasar pengetahuan bahasa Arab. ${ }^{4}$

Agar pengajaran menjadi lebih efektif dan afektif, pembelajar seharusnya dipahami lebih dari sekedar penerima pasif pengetahuan, melainkan seseorang yang secara aktif terlibat dalam proses pembelajaran yang diarahkan oleh guru menuju lingkungan kelas yang nyama dan kondisi emosional, sosiologis, psikologis, dan fisiologis yang kondusif. Selain itu, yang membuat pengajaran menjadi efektif adalah bagaimana guru berusaha menjadi panutan (modelling) dengan memperlihatkan kepribadian dan sikapnya yang positif, berpengalaman berpengalaman dalam mengajar, cakap dalam menyampaikan informasi, reflektif, motivatoris, dan bergairah untuk juga turut belajar. ${ }^{5}$

Permasalahan perkembangan bahasa Arab yang masih cenderung stagnan ini belum terselesaikan, bahasa Arab sudah dihadapkan pada berbagai tantangan. Di antaranya adalah arus globalisasi yang menyebabkan pelajar lebih memilih belajar bahasa Inggris, Jerman, dan Prancis sebagai bahasa asing ketimbang bahasa Arab. Bahkan, hal ini pun menimpa pelajar Timur Tengah. Hal tersebut menyebabkan semakin rendahnya peminat dari kaum terpelajar untuk belajar bahasa Arab. Tantangan lain yang dihadapkan pada bahasa Arab adalah rendahnya minat dan motivasi untuk belajar bahasa Arab. ${ }^{6}$

\footnotetext{
${ }^{4}$ Fathul Mujib, Nailur Rahmawati. Metode Permainan-Permainan Edukatif Dalam Belajar Bahasa Arab... Hlm. 7.

${ }^{5}$ Miftahul Huda. Model-Model Pengajaran dan Pembelajaran. (Yogyakarta: Pustaka Pelajar Offset, 2003), cet. I, hlm. 7.

6 Ulin Nuha. Metodologi Super Efektif Pembelajaran Bahasa Arab. (Yogyakarta: Diva Press, 2012), cet. I, hlm. 21.
} 
Mengajar bahasa Arab bukan sekedar untuk menyampaikan atau mentransfer ilmu saja, tetapi juga sebagai usaha menciptakan sistem pembelajaran yang baik agar tujuan pengajaran dapat tercapai secara optimal. Dalam kasus ini, Mengajar memerlukan suatu metode pembelajaran yang sesuai dan tepat. Mutu pengajaran tergantung pada pemilihan metode yang tepat bagi tujuan yang ingin dicapai, terutama dalam upaya mengembangkan kreatifitas dan inspirasi peserta didik.

Keberhasilan pembelajaran itu sangat berkaitan dengan metode pembelajaran. Metode pembelajaran yang tepat dapat menuntun peserta didik untuk berpikir mandiri, kreatif dan adaptif terhadap berbagai situasi. Sebaliknya, metode yang tidak tepat dapat berakibat fatal, bahkan bisa menyebabkan gagalnya pembelajaran. Belajar yang tidak menggairahkan bagi peserta didik dapat membuat kegiatan pembelajaran kurang harmonis. Di sinilah seorang guru harus berperan aktif dalam menciptakan suasana belajar yang menyenangkan dan dapat meningkatkan semangat peserta didik untuk memperoleh hasil pembelajaran yang optimal.

Dalam proses pembelajaran setiap guru dari berbagai lembaga pendidikan memiliki metodenya masing-masing dalam mengajar karena metode adalah komponen yang sangat penting dalam proses pembelajaran. Metode harus diterapkan agar peserta didik tidak merasa bosan dan mampu menyerap materi dengan baik namun demikian, tidak semua guru berhasil menerapkan metode dengan baik, disebabkan oleh bermacam-macam faktor. Walaupun demikian seorang guru harus berusaha untuk menyusun metode dengan baik agar tujuan pembelajaran yang diinginkan dapat tercapai.

Pada umumnya setiap guru maupun siswa mengalami permasalahan dalam proses pembelajaran yang disebabkan oleh metode pembelajaran yang kurang efektif, sama halnya di Mas Bahrul Hikmah yang juga memiliki permasalahan yang sama, 
yaitu kurangnya minat belajar siswa khususnya bahasa Arab, dan adanya problematika lain dalam proses pembelajaran, hal ini juga disebabkan kurangnya metode inovatif yang dapat diterapkan seorang guru, sehingga tidak ada peningkatan dari segi nilai maupun pengetahuan siswa secara mendalam terhadap bahasa Arab.

Berangkat dari permasalahan tersebut, hal ini dianggap penting untuk diangkat dalam penelitian, karena penulis ingin mengetahui macam-macam metode yang digunakan serta mengetahui metode yang diterapkan guru dalam upaya meningkatkan motivasi belajar bahasa Arab selama proses pembelajaran di Mas Bahrul Hikmah yang terletak di Kabupaten Konawe Utara Provinsi Sultra, penelitian ini dilakukan pada siswa.

Adapun yang menjadi rumusan masalah yaitu, metode apa saja yang diterapkan selama proses pembelajaran di Mas Bahrul Hikmah Konawe Utara dan bagaimana motivasi belajar siswa Mas Bahrul Hikmah Konawe Utara. Penelitian ini bertujuan untuk mengetahui metode apa saja yang diterapkan selama proses pembelajaran di Mas Bahrul Hikmah Konawe Utara dan untuk mengetahui bagaimana motivasi belajar siswa Mas Bahrul Hikmah Konawe Utara. Dengan adanya penelitian ini penulis berharap dari segi teoritik dapat menjadi karya ilmiah yang mampu memperkaya wawasan pengetahuan mengenai metode seorang guru bahasa Arab dalam mengajar, dari segi praktek, diharapkan dapat menyumbangkan pemikiran bagi para pendidik tentang pentingnya sebuah metode dalam mengajar yang harus dikembangkan dalam meningkatkan motivasi belajar bahasa Arab siswa, dan hasil penelitian ini dapat dijadikan informasi bagi para pendidik dalam menerapkan metode yang baik dalam proses pembelajaran. 


\section{Metode}

Jenis penelitian yang digunakan dalam penelitian ini adalah penelitian kualitatif dengan menggunakan analisis deskriptif. Deskriptif adalah suatu metode dalam meneliti suatu kelompok manusia, status obyek, suatu set kondisi atau suatu pemikiran dalam kelompok pada peristiwa yang terjadi pada masa sekarang. Penelitian deskriptif dirancang untuk memperoleh tentang keadaan, status, atau gejala pada saat penelitian dilakukan. Penggunaan metode deskriptif yang dimaksud dalam penelitian ini adalah memperoleh gambaran secara menyeluruh mengenai permasalahan yang diteliti berkaitan dengan penggunaan metode ganjaran dalam meningkatkan motivasi belajar Bahasa Arab siswa di Mas Bahrul Hikmah Konawe Utara Sultra. Penelitian ini dilaksanakan di Mas Bahrul Hikmah Konawe Utara. Pemilihan lokasi tersebut didasarkan atas pertimbangan bahwa di Mas Bahrul hikmah belum pernah dilakukan penelitian tentang penggunaan metode ganjaran dalam meningkatkan motivasi belajar siswa.

Data penelitian ini terdiri atas data primer dan data sekunder. Data primer atau data utama diperoleh dari hasil wawancara dengan para informan yang dipilih dengan menggunakan metode snowball sampling yakni menentukan terlebih dahulu informan kunci kemudian ditentukan informan lain (informan pendukung) berdasarkan kebutuhan penelitian dan petunjuk yang diberikan informan kunci atau informan sebelumnya. Adapun data sekunder atau data pendukung diperoleh dari dokumen sekolah dan bahan-bahan atau referensi kepustakaan yang relevan dengan judul penelitian.

Penelitian, disamping perlu menggunakan metode yang tepat, juga perlu memilih teknik dan alat pengumpulan data yang relevan. Penggunaan teknik dan alat pengumpul data 
yang tepat memungkinkan diperolehnya data yang objektif. Adapun tekhnik pengumpulan data yang digunakan dalam penelitian ini adalah sebagai berikut: a) Teknik wawancara (interview), yakni melakukan Tanya jawab langsung untuk kemudian dicatat dan diredaksikan ke dalam artikel dengan informan kunci yakni seorang guru dengan menggunakan pedoman wawancara yang disesuaikan di lapangan penelitian. b) Teknik dokumentasi yakni mengumpulkan seluruh dokumen sekolah yang berkaitan dengan penelitian baik dalam bentuk foto-foto, kearsipan, atau bentuk-bentuk dokumen sekolah menyangkut sejarah berdirinya sekolah, data sarana prasarana, data guru, siswa dan data-data kearsipan sekolah lainnya.

Selanjutnya, data yang diperoleh dari penelitian ini akan dianalisis agar memperoleh data yang valid untuk kemudian disajikan sesuai dengan masalah yang dibahas. Dalam penelitian ini penulis akan menggunakan tiga tahap dalam melakukan analisis data yaitu: a) Reduksi data, yaitu semua data di lapangan dianalisis sekaligus dirangkum, dipilih halhal yang pokok dan memfokuskan pada hal-hal yang penting, selanjutnya dicari tema dan polanya sehingga data yang telah direduksi akan memberikan gambaran yang lebih jelas, dan mempermudah peneliti untuk melakukan pengumpulan data selanjutnya. b) Display data, yaitu teknik yang digunakan oleh peneliti agar data yang diperoleh yang banyak jumlahnya dapat dikuasai dan dipilih secara fisik dan dibuat dalam bagan. Dengan mendisplaykan data, maka akan memudahkan untuk memahami apa yang terjadi, merencanakan kerja selanjutnya berdasarkan apa yang telah dipahami tersebut. Membuat display merupakan analisis pengambilan keputusan. c) Verifikasi data, yaitu teknik analisis data yang dilakukan oleh peneliti dalam rangka mencari makna data dan mencoba untuk mengumpulkannya. Pada awal kesimpulan data masih kabur penuh 
dengan keraguan tetapi dengan bertambahnya data dan diambil suatu kesimpulan pada akhirnya akan ditemukan dengan mengelola data di lapangan. ${ }^{7}$

Pengujian keabsahan data dilakukan untuk menghindari data yang bias atau tidak valid. Teknik pemeriksaan keabsahan data dengan memanfaatkan sesuatu yang lain diluar data yang ada untuk kepentingan pengecekan keabsahan atau sebagai bahan perbandingan terhadap data yang ada. Triangulasi dilakukan untuk mengecek keabsahan data yang terdiri dari sumber, metode, penyidik dan teori.

Pengujian keabsahan data dalam penelitian ini, penulis akan menggunakan 3 macam triangulasi yaitu: a) Triangulasi sumber yaitu dengan membandingkan dan mengecek kembali derajat kepercayaan suatu informasi yang diperoleh dari lapangan penelitian melalui sumber yang berbeda. b) Triangulasi metode dilakukan dengan cara membandingkan hasil data observasi dengan data hasil wawancara, dengan demikian data yang telah dirumuskan akan disimpulkan kembali untuk memperoleh derajat dan sumber sehingga menjadi data akhir autentik sesuai masalah penelitian ini. c) Triangulasi waktu dilakukan untuk membuktikan apakah data yg diperoleh dapat konsisten pada waktu yang berbeda. ${ }^{8}$

\section{Hasil dan Pembahasan}

Dalam bahasa Arab istilah yang sering dipakai untuk menunjuk kata metode adalah thariqah. ${ }^{9}$ Maksud metodologi pembelajaran bahasa Arab adalah cara atau jalan yang ditempuh bagaimana menyajikan bahan-bahan pelajaran dan bahasa Arab. Agar mudah diterima, diserap dan dikuasai anak

7 Sugiono. Metode Penelitian Kuantitatif Kualitatif dan R\&D. (Bandung: Alfabeta, 2011), hlm. 247.

8 Sanafiah faisal. Metodologi Penelitian Sosial. (Jakarta: Erlangga, 2001), hlm. 33.

9 Suja'i. Inovasi Pembelajaran Bahasa Arab. (Semarang: Walisongo Press, 2008), cet. I, hlm. 31. 
didik dengan baik dan menyenangkan. ${ }^{10}$ Metode menurut KBBI adalah cara kerja yang bersistem untuk memudahkan pelaksanaan suatu kegiatan guna mencapai tujuan yang ditentukan. Metode lebih bersifat prosedural dan sistemik karena tujuannya untuk mempermudah pengerjaan suatu pekerjaan. ${ }^{11}$

Menurut Fathurrahman Pupuh, metode diartikan sebagai suatu cara atau prosedur yang dipakai untuk mencapai tujuan tertentu. Dalam kaitannya dengan pembelajaran, metode didefinisikan sebagai cara-cara menyajikan bahan pelajaran pada peserta didik untuk tercapainya tujuan yang telah ditetapkan. Dengan demikian, salah satu keterampilannya yang harus dimiliki oleh seorang guru dalam pembelajaran adalah keterampilan memilih metode. Pemilihan metode terkait langsung dengan usaha-usaha guru dalam menampilkan pengajaran yang sesuai dengan situasi dan kondisi, sehingga pencapaian tujuan pengajaran diperoleh secara optimal. ${ }^{12}$

Kurang efektifnya pembelajaran bahasa Arab yang ada di sekolah, pondok pesantren atau masyarakat salah satu sebabnya karena pendekatan dan metode yang dipakai selama ini kurang sesuai dengan jiwa dan karakter anak didik. Padahal metode dalam pembelajaran memiliki fungsi yang sangat urgen, sebagaimana pernah dikatakan oleh Muhammad Yunus: al-thariqah ahammu min al-maddah (metode lebih penting daripada materi). ${ }^{13}$

Metode belajar tidak ada yang paling tepat karena antara satu dengan yang lain pada dasarnya adalah saling

10 Ahmad Izzan. Metodologi Pembelajaran Bahasa Arab. (Bandung: Humaniora, 2009), cet. III, hlm. 72.

${ }^{11}$ Iskadarwassid, Dadang Sunendar. Strategi Pembelajaran Bahasa. (Bandung: Pt Remaja Rosdakarya Offset, 2013), cet. IV, hlm. 56.

12 Hamruni. Strategi dan Model-Model Pembelajaran Aktif Menyenangkan. (Yogyakarta: Fakultas Tarbiyah UIN Sunan Kalijaga Yogyakarta, 2009), hlm. 6.

${ }^{13}$ Suja'i. Inovasi Pembelajaran Bahasa Arab... Hlm. 32. 
melengkapi. Oleh sebab itu, penggunaan metode yang bervariasi akan memudahkan pola studi bahasa arab yang sangat minim jam pertemuan di kelas. Suatu hal yang menjadi penting kaitannya denga metode adalah kecermatan dan ketepatan seorang guru dalam memilih dan menghubungkan metode dengan unsur-unsur pembelajaran yang lainnya, seperti materi, peserta didik, jam pelajaran atau waktu yang direncanakan dan media atau alat yang tersedia. ${ }^{14}$

Adapun tujuan sebuah metode yang pertama, pentingnya penanaman "method" hanyalah agar supaya kita mempunyai sesuatu yang dapat dicanteli untuk menggantungkan gagasangagasan kita dalam pengajaran bahasa. Kedua, label "method" memberikan rasa stabil (stability) semacam kepercayaan atau keyakinan (confidence), dan rasa aman (security) kepada murid dan guru. Dan para gurupun sadar bahwa mereka bergandengan dengan orang lain pada dunia yang sama; dunia pengajaran bahasa Asing. ${ }^{15}$

Metode pengajaran adalah cara-cara pelaksanaan dari proses pengajaran, atau bagaimana teknisnya sesuatu bahan pelajaran diberikan kepada murid-murid di sekolah. Dalam pengajaran bahasa arab, metode merupakan salah satu sarana untuk mencapai tujuan pengajaran tersebut. Makin tepat metodenya, diharapkan efektif pula dalam pencapaian tujuan pengajaran tersebut.

Menurut Tayar Yusuf dan syaiful Anwar, ada beberapa metode pengajaran bahasa Arab, yakni: a) Metode Bercakapcakap (Muhadatsah). Metode muhadatsah yaitu cara menyajikan bahan pelajara bahasa Arab melalui percakapan, dalam percakapan itu dapat terjadi antara guru dengan murid atau antara murid dengan murid, sehingga dapat memperkaya

${ }^{14}$ Suja'i. Inovasi Pembelajaran Bahasa Arab... Hlm. 33.

${ }^{15}$ Nurcholish Madjid. Bahasa Arab dan Metode Pengajarannya. (Yogyakarta: Pustaka Pelajar, 2003), cet. I, hlm. 20. 
perbendaharaan kata-kata (vocabulary). Pelajaran muhadatsah merupakan pelajaran bahasa Arab yang pertama kali diberika. Percakapan hendaklah dimulai dari hal yang sederhana atau barang/perkakas yang sudah biasa dlihat oleh siswa setiap hari. Misalya, perkakas sekolah, perkakas rumah tangga dan sebagainya. Atau bisa juga pekerjaan yang biasa dikerjakan oleh siswa, umpamanya duduk, berdiri, makan, minum dan sebagainya. ${ }^{16}$ Oleh karena itu metode utama dan pertamanya di dalam kegiatan belajar dan mengajar bahasa asing itu semestinya adalah metode percakapan (conversational method.${ }^{17}$ b) Metode Membaca. Metode ini dikembangkan berdasarkan asumsi bahwa pengajaran bahasa tidak bisa bersifat multi-tujuan, dan bahwa kemampuan membaca adalah tujuan yang paling realistis ditinjau dari kebutuhan pembelajar bahasa asing dan kemudahan dalam pemerolehannya. Kemahiran membaca merupakan bekal bagi pembelajar untuk mengembangkan pengetahuannya secara mandiri. ${ }^{18}$

Metode membaca selain menekankan kemampuan membaca diam, juga memandang penting kemampuan pengucapan yang benar, sehingga membaca secara nyaring merupakan kegiatan yang banyak dilatihkan. Kemampuan ini dipandang dapat membantu para pelajar/mahasiswa dalam pengungkapan lisan. Sedangkan penguasaan kaidah gramatika merupakan kemampuan yag dikembangkan kemudian, itu juga kaidah-kaidah yang sikiranya diperlukan oleh pembaca di dalam membaca. ${ }^{19}$ Metode membaca (reading method) yaitu menyajikan materi pelajaran dengan cara terlebih dahulu

16 Ahmad Muhtadi Anshor. Pengajaran Bahasa Arab, Media dan Metode-Metodenya. (Yogyakarta: Teras, 2009), Cet. I, hlm. 55.

${ }^{17}$ Ahmad Izzan. Metodologi Pembelajaran Bahasa Arab... Hlm. 90.

18 Ahmad Fuad effendy. Metodologi Pengajaran Bahasa Arab. (Malang: Misykat, 2012), cet. 5, hlm. 54.

19 Acep Hermawan. Metodologi Pembelajaran Bahasa Arab... Hlm. 193. 
mengutamakan membaca, yakni guru mula-mula membacakan topik-topik bacaan, kemudian diikuti oleh siswa. Atau menunjuk salah satu di antara siswa untuk membacakan pelajaran dan siswa lain memperhatikan dan mengikutinya. ${ }^{20} \mathrm{c}$ ) Metode Gramatika. Grammar method sebuah metode pembelajaran dengan cara menghafalkan aturan-aturan gramatika (dalam kaitannya dengan bahasa Arab adalah nahwu dan sharaf) beserta beberapa kata khusus. Kemudian, kata-kata tersebut dirangkaikan menjadi sebuah kalimat berdasarkan gramatika yang hebat. Oleh sebab itu, metode belajar bahasa yang semacam ini merupakan penerapan kaidah-kaidah gramatika dalam bahasa.

Dalam grammar method, guru tidaklah mengajarkan kemahiran berbahasa, tetapi terfokus pada pembelajaran gramatika (nahwu dan sharaf). Pada metode ini, guru berasumsi bahwa gramatika atau kaidah-kaidah bahasa adalah lebih penting dibandingkan dengan kemahiran menggunakannya (kemahiran berbahasa). Penjelasan tersebut dapat ditarik sebuah pemahaman bahwa pembelajaran tentang menggunakan bahasa (menyimak, mendengar, dan berbicara) sama sekali diabaika dalam kegiatan pembelajaran bahasa. Grammar method pulalah yang selama ini paling banyak diterapkan dalam kegiatan pembelajaran bahasa di Indonesia. Maka, tidaklah heran jika para ulama dan cendekiawan muslim di Indonesia mahir membaca kitab kuning atau kitab gundul, namun mereka sangat lemah dalam hal mendengar dan berbicara menggunakan bahasa asing tersebut. Mereka sangatlah ahli dalam mengurai semua penjelasan yang ada dalam sebuah kitab gundul, tetapi sangat lemah dalam berkomunikasi. ${ }^{21}$ Dan d) Metode dikte/Imla. Metode imla disebut juga

20 Ahmad Muhtadi Anshor. Pengajaran Bahasa Arab, Media dan Metode-Metodenya... Hlm. 72.

${ }^{21}$ Ulin Nuha. Metodologi Super Efektif Pembelajaran Bahasa Arab... Hlm. 194. 
metode dikte atau metode menulis dimana guru membacakan materi pelajaran da siswa disuruh menulisnya di buku tulis. Imla juga dapat dilakukan dengan cara guru menuliskan materi pelajaran imla di papan tulis kemudian dihapus dan menyuruh siswa untuk menulisnya kembali di bukunya. ${ }^{22}$

Metode ini amat perlu diterapkan mendampingi semua metode-metode pengajaran bahasa asing. Dalam satu jam penyajian pengajaran bahasa asing semestinya harus menerapkan 3 atau 4 macam metode secara bervariasi dan berselingan, sehingga para pelajar dapat menguasai segala segi-segi keterampilan berbahasa asing: peka pendengaran, terapi percakapan, bagus bacaan, benar tulisan/tidak salah-salah tulis, lancar mengarang, dan baik di dalam berbagai segi berbahasa asing itu. Dictation Method memusatkan tujuannya untuk banyak melatih siswa secara berulang-ulang sehingga mencapai kemampuan menuliskan kata-kata/kalimat-kalimat atau ejaan-ejaan bahasa asing tersebut dengan betul/terhindar dari banyak kesalahan. ${ }^{23}$

Selain metode yang telah dijabarkan sebelumnya, masih banyak metode lainnya dalam proses pembelajaran. Akan tetapi, sedikit berbeda dengan metode sebelumnya. Jika metode yang sebelumnya bersifat khusus untuk digunakan dalam pembelajaran bahasa, maka metode-metode ini lebih cenderung bersifat umum (tidak hanya untuk pembelajaran bahasa). Walaupun bersifat umum, tidak menutup kemungkinan metode ini bisa dipakai untuk pembelajaran bahasa. Tentunya, dengan berbagai modifikasi yang harus dilakukan oleh guru atau tenaga pendidik. Adapun yang perlu menjadi penekanan disini adalah bahwa metode-metode yang bersifat umum juga bisa dipakai dalam pembelajaran bahasa asing. Penggunaan tersebut sebagai metode pendamping ataupun

22 Ahmad Muhtadi Anshor. Pengajaran Bahasa Arab, Media dan Metode-Metodenya... Hlm. 59.

${ }^{23}$ Ahmad Izzan. Metodologi Pembelajaran Bahasa Arab... Hlm. 97. 
utama. ${ }^{24}$ Adapun metode-metodenya yaitu, metode ceramah, metode tanya jawab, metode diskusi, metode demonstrasi, metode sosio-drama dan bermain peran, metode karyawisata, metode kerja kelompok, metode simulasi, metode drill, metode pemberian tugas, metode eksperimen, dan metode pemecahan masalah.

Salah satu unsur yang kurang diperhatikan dalam proses pembelajaran adalah pemberian motivasi belajar oleh guru kepada peserta didiknya. Sesungguhnya dorongan seseorang untuk melakukan sesuatu aktivitas itu sangat penting. Dalam hubungannya dengan kegiatan belajar adalah bagaimana menciptakan kondisi atau suatu proses yang mengarah kepada peserta didik untuk melakukan kegiatan belajar. Dalam hal ini peranan guru sangat penting. Dan untuk belajar dengan baik, diperlukan proses dan motivasi yang baik pula. ${ }^{25}$

Dengan "motif" dimaksud segala daya yang mendorong sesorang untuk melakukan sesuatu. Bila seorang anak tidak berbuat seperti seharusnya, maka harus diselidiki apa sebabnya. Sebab-sebab ini sering bermacam-macam, mungkin ia tak sanggup, sakit, lapar, benci kepada pekerjaan atau kepada guru, tak pandai belajar, sibuk dengan pekerjaan lain, dan sebagainya.

Dengan motivasi dimaksud usaha-usaha untuk menyediakan kondisi-kondisi sehingga anak itu mau, ingin melakukannya. Bila ia tidak suka, ia akan berusaha untuk mengelakkannya. Anak-anak akan giat mengangkat batu untuk mendirikan benteng dalam permainan perang-perangan, tetapi mereka tidak sudi menggeser sebuah batu pun kalau pekerjaan itu tidak menarik, kecuali dengan paksaan dan pengawasan. Anakyang mempunyai inteligensi tinggi mungkin

${ }^{24}$ Ulin Nuha. Metodologi Super Efektif Pembelajaran Bahasa Arab... Hlm. 224.

25 Wa Muna. Metodologi Pembelajaran Bahasa Arab. (Yogyakarta: Teras, 2011) , Cet. I, hlm. 8. 
gagal dalam pelajaran karena kekurangan motivasi. Hasil yang baik tercapai dengan motivasi yang kuat. Anak gagal tak begitu saja dapat dipersalahkan. Mungkin gurulah yang tak berhasil memberi motivasi yang membangkitkan kegiatan pada anak.

Memberi motivasi bukan pekerjaan yang mudah. Motivasi yang berhasil bagi seorang anak atau suatu kelompok mungkin tak berhasil bagi anak atau kelompok lain. ${ }^{26}$ Motivasi berasal dari kata latin "Movere" yang berarti "Dorongan atau daya penggerak". Motivasi ini hanya diberikan kepada manusia, khususnya kepada para bawahan atau pengikut. ${ }^{27}$

Menurut Mc. Donald, motivasi adalah perubahan energy dalam diri seseorang yang ditandai dengan munculnya "feeling" dan didahului dengan tanggapan terhadap adanya tujuan. Dari pengertian yang dikemukakan Mc. Donald ini mengandung tiga elemen penting. 1) Bahwa motivasi itu mengawali terjadinya perubahan energy pada diri setiap individu manusia. Perkembangan motivasi akan membawa beberapa perubahan energy di dalam sistem "neurophysiological" yang ada pada organisme manusia karena menyangkut perubahan energy manusia (walaupun motivasi itu muncul dari dalam diri manusia), penampakkannya akan menyangkut kegiatan fisik manusia. 2) Motivasi ditandai dengan munculnya, rasa/feeling, afeksi sesorang. Dalam hal ini motivasi relevan dengan persoalan-persoalan kejiwaan, afeksi dan emosi yang dapat menentukan tingkah laku manusia. 3) Motivasi akan dirangsang karena adanya tujuan. Jadi motivasi dalam hal ini sebenarnya merupakan respons dari suatu aksi, yakni tujuan. Motivasi memang muncul dari dalam diri manusia, tetapi kemunculannya karena terangsang/terdorong oleh adanya

26 Nasution. Didaktik Asas-Asas Mengajar. (Jakarta: Bumi Aksara, 1995), cet. I, hlm. 73.

27 Melayu S.P. Hasibuan. Organisasi dan Motivasi Dasar Peningkatan Produktivitas. (Jakarta: Bumi Aksara, 1996), hlm. 92. 
unsur lain, dalam hal ini adalah tujuan. Tujuan ini akan menyangkut soal kebutuhan.

Dengan tiga elemen di atas, maka dapat dikatakan bahwa motivasi itu sebagai sesuatu yang kompleks. Motivasi akan menyebabkan terjadinya suatu perubahan energi yang ada pada diri manusia, sehingga akan bergayut dengan persoalan gejala kejiwaan, perasaan dan juga emosi, untuk kemudian bertindak atau melakukan sesuatu. Semua ini didorong karena adanya tujuan, kebutuhan atau keinginan. ${ }^{28}$

Motif merupakan pendorong bagi suatu organisme untuk melakukan sesuatu. Seseorang tidak akan mau berusaha mempelajari sesuatu dengan sebaik-baiknya jika ia tidak mengetahui pentingya dan faedahnya dari hasil yang akan dicapai dari belajar. ${ }^{29}$ Motivasi adalah suatu dorongan atau penggerak untuk melakukan sesuatu yang dapat berasal dari dalam diri individu (intrinsik) maupun yang berasal dari luar individu (ekstrinsik), yaitu dipengaruhi oleh faktor lingkungan, baik lingkungan keluarga, atau sahabat yang ditandai dengan sikap (afektif) dan reaksi untuk mencapai tujuan tertentu. Dengan demikian motivasi berpengaruh terhadap adanya kegiatan.

Ada tiga fungsi motivasi, yaitu: 1) Mendorong manusia untuk berbuat, jadi sebagai penggerak atau motor yang melepaskan energi. Motivasi dalam hal ini merupakan motor penggerak dari setiap kegiatan yang akan dikerjakan. ${ }^{30}$ 2) Menentukan arah perbuatan, yakni ke arah tujuan yang hendak dicapai. $^{31}$ 3) Menyeleksi perbuatan, yakni menentukan perbuatan-perbuatan apa yang harus dikerjakan yang serasi guna

${ }^{28}$ Sardiman. Interaksi dan Motivasi Belajar Mengajar. (Rajawali Pers, 2010), hlm. 73.

29 Muhammad Thobroni, Arif Mustofa. Belajar dan pembelajaran. (Yogyakarta: Ar-Ruzz Media, 2011), cet. I, hlm. 33.

${ }^{30}$ Sardiman. Interaksi dan Motivasi Belajar Mengajar... Hlm. 85.

${ }^{31}$ Nasution. Didaktik Asas-Asas Mengajar... Hlm. 77. 
mencapai tujuan, dengan menyisihkan perbuatan-perbuatan yang tidak bermanfaat tersebut. Seseorang siswa yang akan menghadapi ujian dengan harapan dapat lulus, tentu akan melakukan kegiatan belajar dan tidak akan menghabiskan waktunya untuk bermain kartu atau membaca komik, sebab tidak serasi dengan tujuan.

Disamping itu, ada juga fungsi-fungsi lain. Motivasi dapat berfungsi sebagai pendorong usaha dan pencapaian prestasi. seseorang melakukan suatu usaha karena adanya motivasi. Adanya motivasi yang baik dalam belajar akan menunjukkan hasil yang baik. Dengan kata lain, dengan adanya usaha yag tekun dan terutama didasari adanya motivasi, maka seseorang yang belajar itu akan dapat melahirkan prestasi yang baik. Intensitas motivasi seorang siswa akan sangat menentukan tingkat pencapaian prestasi belajarnya. ${ }^{32}$

\section{Metode yang diterapkan di Mas Bahrul Hikmah Konawe Utara}

Penggunaan sebuah metode adalah hal yang sangat penting dalam proses pembelajaran, selain untuk meningkatkan motivasi belajar siswa, juga sangat penting untuk meningkatkan kualitas seorang guru, yakni ditinjau dari segi profesionalitasnya dalam melaksanakan sebuah proses pembelajaran, banyak hal-hal yang menjadi permasalahan dalam proses pembelajaran tersebut, selain didasari oleh siswa yang kurang memiliki minat, juga seorang guru yang tidak pandai dalam memanfaatkan sebuah metode pembelajaran, sehingga proses pembelajaran kurang efektif karena kurangnya ide-ide inovatif terhadap penggunaan metode itu sendiri.

Dalam kegiatan pembelajaran, sangat penting bagi seorang guru untuk mempunyai berbagai metode. Ia harus mempunyai wawasan yang luas tentang bagaimanakah

${ }^{32}$ Sardiman. Interaksi dan Motivasi Belajar Mengajar... Hlm. 85. 
kegiatan pembelajaran itu terjadi, dan langkah-langkah apakah yang harus ia tempuh dalam kegiatan tersebut. Jika seorang guru tidak mempunyai metode dalam mengajar, apalagi tidak menguasai materi yang hendak disampaikan, maka kegiatan pembelajaran tersebut tidak akan maksimal, bahkan cenderung gagal.

Bagi seorang guru, wawasan mengajar ini sebenarnya merupakan garis-garis besar haluan untuk bertindak dalam rangka mencapai tujuan yang telah ditetapkan sebelumnya. Jadi, seorang guru harus paham dan menguasai metode secara total. ${ }^{33}$ Dari hasil wawancara peneliti dengan salah seorang guru di Mas Bahrul Hikmah Konawe Utara Sultra mengatakan bahwa, metode-metode yang selama ini diterapkan dalam proses pembelajaran adalah metode-metode yang pada umumnya digunakan oleh guru-guru dalam proses pembelajaran.

Adapun metode yang diterapkan ketika proses pembelajaran bahasa Arab adalah, metode percakapan atau dikenal dengan muhadatsah, dengan percakapan seorang siswa bisa praktek langsung dan lebih memudahkan siswa dalam menguasai percakapan bahasa Arab, metode membaca yaitu qira'ah (muthala'ah) dengan membaca siswa lebih mudah memahami isi bacaan dan akan lebih pintar dalam membaca tulisan-tulisan Arab metode ini biasa digunakan ketika proses pembelajaran muthalaah siswa membaca kemudian mejelaskan makna dari bacaan, metode gramatika atau qowa'id (alkitabah) dengan cara ini siswa lebih gampang mengingat cara penulisan serta mengetahui kaidah yang benar dalam penulisan bahasa Arab metode ini biasa digunakan ketika proses pembelajaran nahwu dan sharaf dan metode mendengarkan

${ }^{33}$ Ulin Nuha. Metodologi Super Efektif Pembelajaran Bahasa Arab... Hlm. 155. 
(al-istima'i) metode ini biasa digunakan ketika proses pembelajaran imla', selain menggunakan metode khusus pembelajaran bahasa Arab juga menggunakan metode-metode umum, seperti metode ceramah, metode diskusi, metode kerja kelompok, metode tanya-jawab dan metode pemberian tugas.

Dalam proses pembelajaran ditemukan adanya kendala yaitu, sebagian siswa masih belum baik dalam membaca tulisan Arab, selain karena pemahaman yang kurang terhadap bahasa Arab itu sendiri, juga disebabkan karena belum fasih dalam membaca al-Qur'an. Hal ini dianggap sebagai permasalahan terbesar dalam pembelajaran bahasa Arab. Selain itu juga karena kurangnya minat siswa untuk mempelajari bahasa Arab sehingga kurangnya motivasi dalam mempelajarinya.

Dari semua metode yang telah diterapkan hanya tiga metode yang bisa sedikit menarik minat siswa yaitu metode percakapan, metode mendengarkan, dan metode kerja kelompok, ketika menerapkan metode ini siswa ternyata lebih banyak bermain daripada belajar dan memahami pelajarannya. Sehingga dari segi nilai tidak ada peningkatan dan bahkan tidak memenuhi standar penilaian.

Dengan adanya permasalahan dalam proses pembelajaran tersebut diterapkanlah metode baru dengan harapan siswa dapat memiliki minat dalam belajar bahasa Arab metode yang diterapkan yaitu, metode ganjaran. Metode ganjaran yang diterapkan yaitu metode pemberian hukuman dan metode pemberian hadiah.

Menurut Sulastri S.Pd.I, metode ini sengaja diterapkan untuk menarik minat atau perhatian seorang siswa dalam belajar, khususnya belajar bahasa Arab. Metode pemberian hukuman diperuntukkan oleh siswa yang nakal, malas belajar, pasif dalam kerja kelompok, pasif ketika proses pembelajaran berlangsung yaitu ketika diterapkannya metode tanya jawab dan juga untuk anak yang tidak mengerjakan tugas di sekolah atau pekerjaan rumah. Sedangkan metode pemberian hadiah 
terkadang hanya anak yang pintar dan rajin yang memiliki minat, akan tetapi tidak menutup kemungkinan bahwa anak yang nakal tidak memiliki minat terhadap metode pemberian hadiah, dan begitu pula sebaliknya.

\section{Motivasi belajar siswa Mas Bahrul Hikmah Konawe Utara}

Motivasi ada dua macam yaitu motivasi intrinsik (dari dalam) dan motivasi ekstrinsik (dari luar). Motivasi intrinsik misalnya, seorang siswa belajar karena didorong oleh keinginan untuk mengetahuinya, sedangkan motivasi ekstrinsik yaitu, seorang siswa belajar supaya mendapat angka yang baik, naik kelas, dan mendapat ijazah.

Dilihat dari jenis motivasinya, Siswa di Mas Bahrul Hikmah ternyata tidak memiliki motivasi intrinsik maupun ekstrinsik dalam belajar bahasa Arab. Motivasi intrinsik memang susah dibangun setiap orang, akan tetapi dengan adanya motivasi ekstrinsik dapat memunculkan adanya motivasi intrinsik.

Setelah diterapkannya metode baru, yakni metode ganjaran (pemberian hadiah dan pemberian hukuman) motivasi belajar bahasa Arab dari siswa muncul seketika. Yang mana guru menerapkan metode pemberian hukuman untuk anakanak yang nakal, pasif dan tidak mengerjakan tugas dengan cara menyuruh siswa menghafalkan kosa kata (mufradat), selain itu jika siswa yang masih lalai terkadang berjemur di luar kelas dengan harapan bahwa tidak mengulangi kesalahan yang sama. Selain hukumannya bermanfaat juga bisa menjadi bahan renungan seorang siswa dan juga dapat menguatkan mentalnya. Dengan metode hukuman ini tentunya akan membuat siswa termotivasi dalam belajar bahasa Arab. Untuk metode pemberian hadiah guru memberi sebuah hadiah kepada siswa yang rajin belajar dan mendapat nilai bagus.

Dari tabel 1 dapat dilihat adanya peningkatan nilai setelah diterapkannya metode ganjaran, nilai sebagian siswa meningkat dari sebelumnya, data diperoleh dari nilai yang mewakili 
setiap kelas yang diterapkannya metode tersebut, yakni dari kelas 10 hingga kelas 12 .

Tabel 1. Tabel Nilai

\begin{tabular}{lcc}
\hline Kelas / Nama siswa & $\begin{array}{c}\text { Nilai sebelum } \\
\text { penggunaan metode } \\
\text { ganjaran }\end{array}$ & $\begin{array}{c}\text { Nilai setelah } \\
\text { penggunaan metode } \\
\text { ganjaran }\end{array}$ \\
\hline $\begin{array}{l}\text { Kelas 10 / Ali } \\
\text { Ikhwanuddin }\end{array}$ & 65 & 85 \\
\hline Nurpian Lambera & 62 & 83 \\
\hline Kelas 11 / Iswanto & 65 & 87 \\
\hline Nurhayati & 65 & 85 \\
\hline Kelas 12 / Mirda & 68 & 87 \\
\hline Aswan & 60 & 75 \\
\hline
\end{tabular}

Untuk siswa yang memperoleh nilai tinggi, yaitu nilai 8587 mendapatkan hadiah sepatu, jilbab, dan dasi. Adapun yang memperoleh nilai 75 keatas mendapatkan sebuah buku dan pulpen.

Tentunya dengan metode ini banyak siswa yang termotivasi, keberhasilan metode ini telah dibuktikan dari nilai yang diperoleh sebelum dan sesudah diterapkan, metode ini memiliki kelemahan, yaitu seorang guru harus mempersiapkan banyak dana untuk memenuhi metode pemberian hadiah, karena setelah siswa mendapat nilai bagus maka seorang guru harus memenuhi janjinya, yaitu memberikan sebuah hadiah. Akan tetapi metode ini sangat efektif untuk meningkatkan motivasi belajar siswa khususnya dalam pembelajaran bahasa Arab.

Penggunaan metode ganjaran di Mas Bahrul Hikmah, sangatlah efektif selain bisa menumbuhkan motivasi siswa dalam belajar juga ada kepuasan seorang guru terhadap nilai yang diperoleh siswanya, maka dari itu penggunaan metode yang baik dan inovatif sangat penting dalam proses pembelajaran, tidak hanya itu seorang siswa juga harus berpartisipasi agar tujuan pembelajaran dapat tercapai. 


\section{Kesimpulan}

Dari uraian diatas dpat disimpulkan bahwa untuk membuat siswa termotivasi adalah dengan cara menciptakan metode-metode pembelajaran yang menarik dengan tujuan menumbuhkan minat siswa dalam belajar. Antara guru dan siswa harus ada interaksi yang baik agar tujuan pembelajaran dapat tercapai dengan baik.

Metode-metode pembelajaran yang diterapkan di Mas Bahrul Hikmah adalah metode-metode yang pada umumnya digunakan guru dalam mengajar bahasa Arab diantaranya adalah metode percakapan (muhadatsah), metode membaca (muthala'ah), metode menulis (al-kitabah), metode mendengarkan (al-istima'i), metode ceramah, metode diskusi, metode kerja kelompok, metode tanya-jawab, metode pemberian tugas dan metode ganjaran.

Dari hasil penerapan metode ganjaran di Mas Bahrul Hikmah dapat disimpulkan bahwa siswa memiliki motivasi yang sangat besar dengan diterapkannya metode tersebut, dan juga nilai ujian siswa meningkat setelah penggunaan metode ganjaran.

\section{Daftar Pustaka}

Anshor Ahmad Muhtadi. 2009. Pengajaran Bahasa Arab, Media dan Metode-Metodenya. Yogyakarta: Teras.

Thobroni Muhammad, Arif Mustofa. 2011. Belajar dan pembelajaran. Yogyakarta: Ar-Ruzz Media.

Iskadarwassid, Dadang Sunendar. 2013. Strategi Pembelajaran Bahasa. Bandung: Pt Remaja Rosdakarya Offset.

Effendy Ahmad Fuad. 2012. Metodologi Pengajaran Bahasa Arab. Malang: Misykat.

Faisal Sanafiah. 2001. Metodologi Penelitian Sosial. Jakarta: Erlangga. 
Penggunaan Metode Ganjaran dalam Meningkatkan Motivasi ...

Hamruni. 2009. Strategi dan Model-Model Pembelajaran Aktif Menyenangkan. Yogyakarta: Fakultas Tarbiyah UIN Sunan Kalijaga Yogyakarta.

Hermawan Acep. 2011. Metodologi Pembelajaran Bahasa Arab. Bandung: PT Remaja Rosdakarya.

Huda Miftahul. 2003. Model-Model Pengajaran dan Pembelajaran. Yogyakarta: Pustaka Pelajar Offset.

Izzan Ahmad. 2009. Metodologi Pembelajaran Bahasa Arab. Bandung: Humaniora.

Madjid Nurcholish. 2003. Bahasa Arab dan Metode Pengajarannya. Yogyakarta: Pustaka Pelajar.

Muna Wa. 2011. Metodologi Pembelajaran Bahasa Arab. Yogyakarta: Teras.

Mujib Fathul, Nailur Rahmawati. 2011. Metode PermainanPermainan Edukatif Dalam Belajar Bahasa Arab. Yogyakarta: Diva Press.

Nasution. 1995. Didaktik Asas-Asas Mengajar. Jakarta: Bumi Aksara.

Nuha Ulin. 2012. Metodologi Super Efektif Pembelajaran Bahasa Arab. Yogyakarta: Diva Press.

Sardiman. 2010. Interaksi dan Motivasi Belajar Mengajar. Rajawali Pers.

Sugiono. 2011. Metode Penelitian Kuantitatif Kualitatif dan R\&D. Bandung: Alfabeta.

Suja'i. 2008. Inovasi Pembelajaran Bahasa Arab. Semarang: Walisongo Press.

S.P. Hasibuan Melayu. 1996. Organisasi dan Motivasi Dasar Peningkatan Produktivitas. Jakarta: Bumi Aksara. 